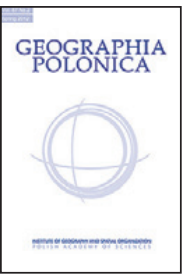

\title{
GEOGRAPHICAL PATTERNS OF SELECTED FEATURES OF THE SOIL AND HERB LAYER IN CENTRAL AND NORTH EUROPEAN SCOTS PINE FORESTS
}

\section{Jerzy Solon ${ }^{1}$ - Marek Degórski}

\author{
Polish Academy of Sciences \\ Institute of Geography and Spatial Organization \\ Twarda 51/55, 00-818 Warszawa: Poland \\ 1 e-mail address: j.solon@twarda.pan.pl, \\ 2 e-mail address: m.degor@twarda.pan.pl
}

\begin{abstract}
This paper defines the relationships between geographical location (which determines macroclimatic differentiation and reflects the history of the vegetation), soils (which determine hydrolytic acidity, degree of base saturation and organic carbon content), and selected characteristics of vegetation (species richness, herb layer biomass, moss layer biomass) in one type of forest community, namely, pine forests of the Vaccinio-Piceetea class. The study area covers the major part of the European domain of pine forests, from $70.15^{\circ} \mathrm{N}$ (Norway) to $50.35^{\circ} \mathrm{N}$ (Poland) and from $12.02^{\circ} \mathrm{E}$ (Sweden) to $33.6^{\circ} \mathrm{E}$ (Russia). The geographical pattern shows the following correlations: (a) a rise in the number of vascular plant species in the herb layer as one moves from west to east and from north to south; (b) no significant relationship between geographical location and the biomass of the herb layer, but it is possible to divide the study area into two parts: central Scandinavia, characterized by a high level of biomass, and the rest of the area, characterized by lower herb layer biomass; (c) a south-north increase in the standard deviation of herb layer biomass (serving also as a measure of spatial heterogeneity of the forest floor in terms of the synusial structure of the community); (d) greater biomass of the bryophyte (moss+lichen) layer in the north than in the south and in the east than in the west; (e) stability at lower latitudes of standard deviation for moss biomass (serving also as a measure of spatial heterogeneity of the forest floor in terms of the synusial structure of the community), albeit with a sharp increase north of latitude $55^{\circ} \mathrm{N}$.
\end{abstract}

Key words

Vaccinio-Piceetea - species richness - species biomass - geographical pattern European pine forests $\bullet$ gradients

\section{Introduction}

Species richness and biomass are among the most important features of forest communities (Mouillot \& Mouquet 2006). They are influenced by a range of factors such as large-scale climatic and habitat differentiation, the history of vegetation development in the Holocene, the history of use and successional interactions. The role of the different factors changes in relation to the scale of the phenomenon of interest (Loreau 2000). Pine (Pinus sylvestris) forests in Europe are one of the best subjects to study geographical patterns of species richness and biomass. Pinus sylvestris as a species is widely distributed in Europe, but habitats suitable for pine-dominated forests occupy less than half of the continent (see discussion in Solon 2003ab). 
Latitudinal gradients in species richness have been recognized for nearly a century. It is well established that the tropics harbour many more species than colder climates. General hypotheses to explain that gradient (Climatic Stability, Seasonality/Equability, Historical Perturbation, Productivity, Intermediate Disturbance, Spatial Heterogeneity, Historical Time, Evolutionary Rate, Supply of Energy, Species-Energy etc. - compare: Brown \& Lomolino 1998; Gaston \& Blackburn 2000; Clarke \& Crame 2003; Currie et al. 2004; Cardillo et al. 2005; Allen et al. 2006) mainly operate on data averaged and aggregated for regions and plant formations or biomes. There is a shortage of detailed studies of geographical patterns of richness and biomass confined to one, well- and narrowly defined, group of plant communities.

In analyses on a supraregional scale, overall geographical factors, including macroclimatic differentiation, are most important (Wright 1983; Kalmar \& Currie 2006). Macroclimatic differentiation consists of many elements, including mean annual temperature, total precipitation, moisture deficit, the amplitude of annual temperatures, the degree of continentality of the climate and the length of the growing season. These elements are mutually interlinked and are dependent on geographical location. Geographical location itself is not an ecological factor, but may be regarded as a composite indicator of macroclimatic differentiation.

\section{Aim of Study}

This paper defines the relationships between geographical location (which determines macroclimatic differentiation and is reflected in the history of the vegetation) and selected characteristics of soils, the species richness of the herb layer, and biomass in one type of forest community, namely, pine forests of the Vaccinio-Piceetea class. It is the basis for: (a) evaluating to what extent the chosen characteristics of soil properties, forest richness, and biomass change regularly according to latitudinal and/or longitudinal gradients; (b) determining the similarity of spatial patterns of these features.

This paper opens the series of integrated studies based on data collected during different expeditions and research projects. Partial results of these projects were published elsewhere (see the next chapter).

\section{Methods}

The analyses were conducted on the basis of data collected from 26 forest stands extending from northern Norway to southern Poland and from southern Sweden and eastern Germany to eastern Belarus. The basic information about the geographic position and climatic characteristics of plots is presented in Table 1. The stands were mature or almost mature pine stands, basically single-species and single-aged (60-95 years). All the forest communities represent the Vaccinio-Piceetea class. Their economic use did not differ significantly. All the sites lay on dry, strongly or slightly acidic soils with low nitrogen content. Different data were collected for each stand to measure or evaluate: (a) species richness and phytoindicative values, (b) biomass of herb and moss layers, and (c) soil properties. The basic unit for the description of species composition (a phytosociological record) was an area covering $400 \mathrm{~m}^{2}$. This unit was used for calculations of the number of species of vascular plants and different ecological indicators. Biomass was determined on all plots. An 11×11 m quadrate was marked off at each study site. Within the quadrate, 12 sampling sites were selected in a regular manner. Circular biomass samples were taken from a $0.1 \mathrm{~m}^{2}$ area. The entire biomass was collected in the field and then sorted into living moss and higher plant biomass. The dead parts of plants were removed. In the laboratory the samples were dried to constant weight at a temperature of $90^{\circ} \mathrm{C}$ and weighed to an accuracy of $0.01 \mathrm{~g}$. The results obtained were recalculated per $\mathrm{m}^{2}$.

Comprehensive soil analyses of both physical and chemical soil characteristics were conducted for each stand. The following parameters were calculated:

- thickness of the soil horizons, as an arithmetic mean of 30 measurements,

- soil texture, using the sieve method and the aerometric method of Bouyoucos as modified by Casagrande and Prószyński (in Dobrzański \& Uziak 1972),

- pH, using a pH-meter (Hach 108),

- electrolytic conductivity (EC), using a conductivity meter (Hach 1108),

- nutrients dissolvable in $20 \% \mathrm{HCl}$, conforming to the Gedroyc procedure (in Dobrzański \& Uziak 1972), using the ASA method, 
Table 1. Geographic location and basic climatic characteristics of the study plots.

\begin{tabular}{|c|c|c|c|c|c|}
\hline \multirow{2}{*}{ Country } & \multirow{2}{*}{$\frac{\text { Longitude }}{\text { (degrees) }}$} & \multirow{2}{*}{$\begin{array}{l}\text { Latitude } \\
\text { (degrees) }\end{array}$} & \multirow{2}{*}{$\begin{array}{l}\text { Annual } \\
\text { precipitation } \\
(\mathrm{mm})\end{array}$} & \multicolumn{2}{|c|}{ Mean temperature $\left({ }^{\circ} \mathrm{C}\right)$} \\
\hline & & & & January & July \\
\hline Norway & 27.788 & 70.150 & 438 & -8.3 & 10.7 \\
\hline Finland & 27.022 & 69.746 & 401 & -11.4 & 11.9 \\
\hline Finland & 26.030 & 64.724 & 494 & -10.8 & 15.5 \\
\hline Finland & 29.282 & 61.662 & 655 & -9.4 & 16.6 \\
\hline Sweden & 12.020 & 58.550 & 776 & -2.6 & 15.9 \\
\hline Russia & 33.602 & 60.470 & 688 & -10.6 & 16.5 \\
\hline Estonia & 24.986 & 58.337 & 659 & -6.0 & 17.0 \\
\hline Latvija & 24.888 & 56.623 & 639 & -5.7 & 17.0 \\
\hline Lithuania & 26.018 & 55.431 & 658 & -6.5 & 16.8 \\
\hline Germany & 12.430 & 53.102 & 572 & -0.5 & 17.5 \\
\hline Poland & 14.537 & 52.661 & 531 & -2.4 & 19.0 \\
\hline Poland & 15.706 & 52.740 & 555 & -2.8 & 19.1 \\
\hline Poland & 16.437 & 52.788 & 557 & -3.4 & 18.4 \\
\hline Poland & 18.739 & 50.582 & 641 & -2.9 & 18.2 \\
\hline Poland & 19.012 & 52.831 & 538 & -4.0 & 18.5 \\
\hline Poland & 19.654 & 50.350 & 708 & -4.0 & 17.3 \\
\hline Poland & 20.419 & 51.108 & 609 & -5.4 & 17.4 \\
\hline Poland & 20.618 & 51.584 & 544 & -4.6 & 18.0 \\
\hline Poland & 22.283 & 52.636 & 542 & -5.8 & 18.3 \\
\hline Poland & 22.940 & 50.447 & 575 & -4.4 & 17.9 \\
\hline Poland & 23.308 & 53.874 & 582 & -5.2 & 16.9 \\
\hline Poland & 23.619 & 52.922 & 578 & -4.9 & 17.6 \\
\hline Belarus & 27.148 & 52.821 & 621 & -6.3 & 18.0 \\
\hline Belarus & 28.430 & 52.873 & 612 & -6.7 & 18.1 \\
\hline Belarus & 31.113 & 53.427 & 598 & -7.8 & 18.1 \\
\hline Belarus & 32.599 & 53.348 & 603 & -8.0 & 18.1 \\
\hline
\end{tabular}

Source: climatic data according to Wordclim database (http://www.worldclim.org/download) - compare Hijmans et al. (2005).

- exchangeable cations $\left(\mathrm{Ca}^{2+}, \mathrm{Mg}^{2+}, \mathrm{K}^{+}, \mathrm{Na}^{+}\right)$, after extraction of samples with $1 \mathrm{M}$ ammonia acetate at $\mathrm{pH} 6.8$, using the ASA method,

- hydrolytic acidity $(\mathrm{H})$ by the method of Kappen (in Dobrzański \& Uziak 1972),

- exchangeable hydrogen (EH), exchangeable aluminium (EAl), and exchangeable acidity (EA), determined using the methods of Sokolov (in Dobrzański \& Uziak 1972).

Other parameters were also calculated:

- total exchangeable bases (S), calculated as the sum of $\mathrm{Ca}^{2+}, \mathrm{Mg}^{2+}, \mathrm{K}^{+}$and $\mathrm{Na}^{+}$,

- capacity of the absorption complex (T), determined as $\mathrm{H}+\mathrm{S}$,

- degree of base saturation $(\mathrm{V})$, determined as $\mathrm{S} / \mathrm{T} \times 100 \%$.

The data gathered were analysed with the help of different procedures. Linear and non-linear regression models were applied to determine the relationships between geographical location and soil and vegetation features, but only those representing the best fits are presented here.
The method of ordinary kriging ${ }^{1}$ in the ArcGis environment was used for interpolation and visualisation of spatial patterns of the features under study.

Other results from study sites (e.g. species composition of the study plots, horizontal diversification of the herb layer and results of biomass measurements) with a complete presentation of the methodologies used can be found in other publications. The Polish sites have been described in Breymeyer et al. (1995), Roo-Zielińska and Solon (1998ac), Solon (1998), Solon and Roo-Zielińska (1998). The results for the longitudinal transect (from eastern Germany to eastern Belarus) have been presented in Roo-Zielińska and Solon (1997,

\footnotetext{
${ }^{1}$ Kriging is a geostatistical procedure that generates an estimated surface from a scattered set of points with $z$-values. Unlike other interpolation methods kriging attempts to express trends suggested in the data and takes the spatial autocorrelation into account. Ordinary kriging assumes that the mean is unknown and the process is locally stationary (Fischer \& Getis 2010).
} 
1998b). The results from sites in Norway, Finland, Estonia, Latvia, Lithuania and some Polish sites (latitudinal transect) are presented in detail in Vucetich et al. (2000), Solon and Roo-Zielińska (2003), Solon (2003ab), while Breymeyer et al. (2006) described overall correlations between ecological (phytoindicative) characteristics, species composition, biomass and intensity of production/decomposition in pine forests on the basis of data from both transects (latitudinal and longitudinal). Detailed data from the sites in Sweden and near St. Petersburg, presented in the broader context of the impact of anthropopression and macrogeographical differentiation are to be found in Roo-Zielińska et al. (2009).

The multi-aspect results of soil research at the study sites have been presented in several specialised publications. Lithological and soil-related aspects were presented in Degórski (1998a), physical and chemical soil characteristics were discussed in Degórski (1998b), and the seasonal dynamics of soil characteristics was presented in Degórski (1998c). Other areas of interest have included the characteristics of the humus, microorganism biomass and nucleic acid content in the soils of coniferous and mixed coniferous forests in a climatic transect (Jefremow \& Degórski 1998) and geographically determined variability in characteristics of soils bearing coniferous forests in Central and Northern Europe (Degórski 2002, 2007).

\section{Results}

\section{Species richness}

Species richness of the herb layer increased rather regularly from West to East and, somewhat less conspicuously, from North to South (Fig. 1), with observed minima below 10 species (northern Finland, western Poland and eastern Germany) and maxima exceeding 40 species per 400 m² $^{2}$ (Belarus). The variability of species richness along the east-west axis was statistically significant and best described by the Saturation Growth-Rate Model (Tab. 2). Importantly, there was no statistically significant correlation with latitude and only a minor effect attributable to the soil characteristics in the study sites. It is worth underlining that species richness was correlated only with the degree of base saturation in the eluvial horizon (VE), but the growing number of species is only visible when VE is higher than 20. Below this threshold the number
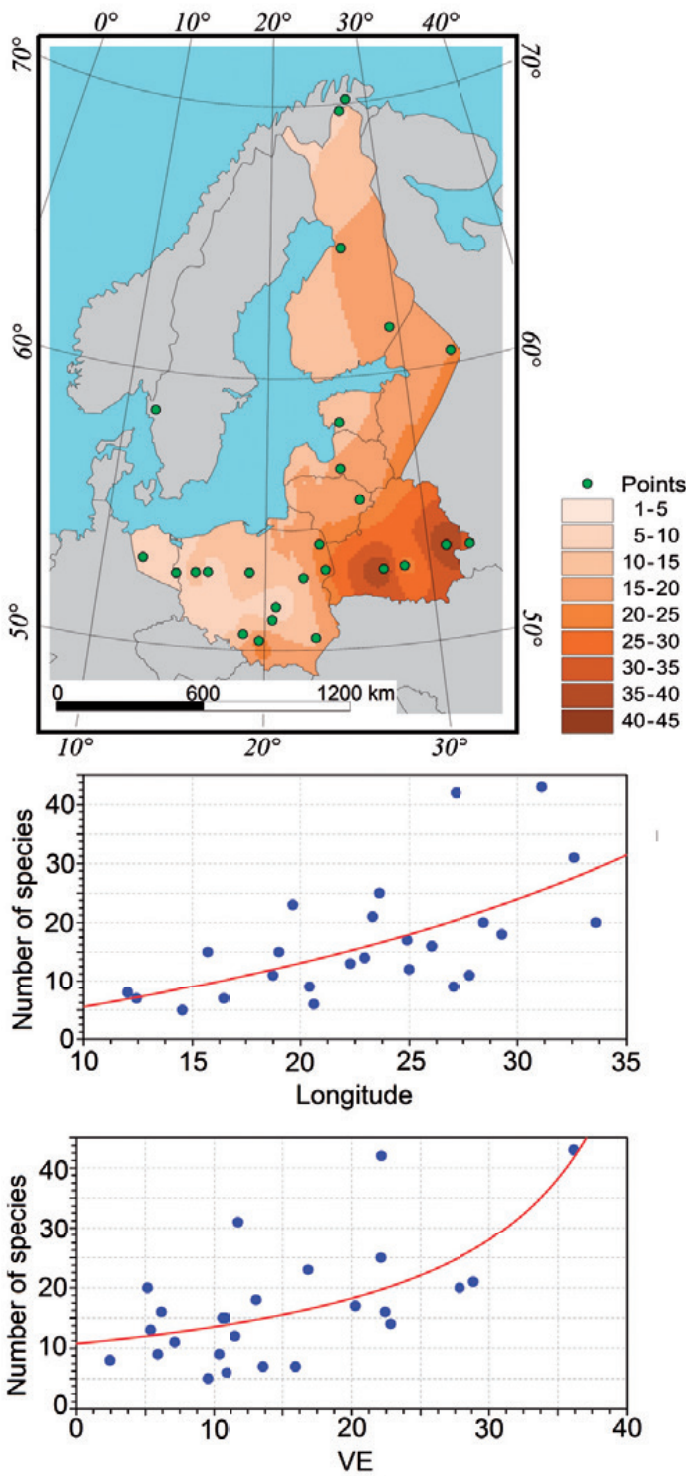

Figure 1. Spatial differentiation of plant species numbers in the herb layer and correlations between species numbers and selected characteristics of the study sites.

of species fluctuates irregularly in the range from 5 to 20 (Fig.1; Tab. 2).

\section{Herb layer biomass}

The spatial variability of herb layer biomass was quite high (Fig. 2), ranging from $<70 \mathrm{~g} / \mathrm{m}^{2}$ (Lithuania and some Polish sites) to $>200 \mathrm{~g} / \mathrm{m}^{2}$ (Sweden and central and northern Finland). The lack of a clear directional gradient coupled with the results of other studies indicates that herb layer 
Table 2. Main models of correlations between variables (parameters rounded to 3 digits).

\begin{tabular}{|c|c|c|c|c|c|c|c|c|c|}
\hline \multirow{2}{*}{$\begin{array}{l}\text { Independent } \\
\text { variable }\end{array}$} & \multirow{2}{*}{ Dependent variable } & \multirow{2}{*}{$\begin{array}{l}\text { Model } \\
\text { name }\end{array}$} & \multirow{2}{*}{$\begin{array}{l}\text { Model } \\
\text { formula }\end{array}$} & \multicolumn{3}{|c|}{ Parameters } & \multirow{2}{*}{$\begin{array}{l}\text { Standard } \\
\text { error }\end{array}$} & \multirow{2}{*}{$\begin{array}{l}\text { Correlation } \\
\text { coefficient }\end{array}$} & \multirow{2}{*}{$\begin{array}{l}\text { Figure } \\
\text { number }\end{array}$} \\
\hline & & & & a & $b$ & c & & & \\
\hline \multirow{2}{*}{$\begin{array}{l}\frac{0}{0} \\
\stackrel{D}{ \pm} \\
\stackrel{ \pm}{0} \\
0 \\
\end{array}$} & number of herb layer species & $\begin{array}{l}\text { Saturation Growth-Rate } \\
\text { Model }\end{array}$ & $y=a x /(b+x)$ & -36.359 & -75.480 & & 7.989 & 0.609 & Fig. 1 \\
\hline & $\begin{array}{l}\text { hydrolytic acidity of eluvial horizon } \\
(\mathrm{HE})\end{array}$ & Vapour Pressure Model & $y=\exp (a+b / x+c \ln (x))$ & -51.682 & 264.800 & 13.230 & 4.337 & 0.795 & Fig. 5 \\
\hline \multirow{4}{*}{ 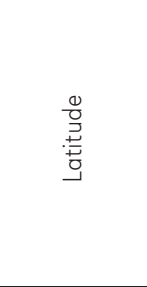 } & $\begin{array}{l}\text { herb layer biomass standard } \\
\text { deviation }\end{array}$ & Logarithm Fit & $y=a+b^{\star} \ln (x)$ & $-1,264.771$ & 332.714 & & 32.025 & 0.705 & Fig. 2 \\
\hline & moss layer biomass & Logarithm Fit & $y=a+b^{\star} \ln (x)$ & $-5,911.851$ & $1,539.146$ & & 168.390 & 0.659 & Fig. 3 \\
\hline & $\begin{array}{l}\text { moss layer biomass standard } \\
\text { deviation }\end{array}$ & Logarithm Fit & $y=a+b^{\star} \ln (x)$ & $-3,416.855$ & 878.347 & & 103.668 & 0.630 & Fig. 3 \\
\hline & $\begin{array}{l}\text { organic carbon in topsoil horizon } \\
\text { (CA) }\end{array}$ & Vapour Pressure Model & $y=\exp (a+b / x+c \ln (x))$ & 257.222 & $-3,067.441$ & -49.920 & 1.405 & 0.643 & Fig. 7 \\
\hline \multirow{4}{*}{ 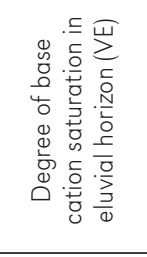 } & herb layer biomass & Hoerl Model & $y=a^{\star}\left(b^{\wedge} x\right)^{\star}\left(x^{\wedge} c\right)$ & 609.769 & 1.054 & -0.937 & 77.510 & 0.489 & Fig. 2 \\
\hline & $\begin{array}{l}\text { herb layer biomass standard } \\
\text { deviation }\end{array}$ & $\begin{array}{l}\text { Saturation Growth-Rate } \\
\text { Model }\end{array}$ & $y=a x /(b+x)$ & 54.673 & -1.687 & & 38.635 & 0.528 & Fig. 2 \\
\hline & $\begin{array}{l}\text { moss layer biomass standard } \\
\text { deviation }\end{array}$ & Hyperbolic Fit & $y=a+b / x$ & 15.015 & 779.128 & & 87.766 & 0.590 & Fig. 3 \\
\hline & number of herb layer species & Reciprocal Model & $y=1 /(a x+b)$ & -0.002 & 0.093 & & 7.747 & 0.652 & Fig. 1 \\
\hline \multirow{5}{*}{ 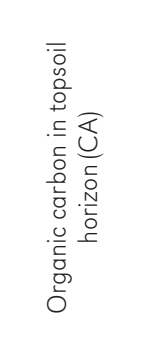 } & $\begin{array}{l}\text { herb layer biomass standard } \\
\text { deviation }\end{array}$ & Modified Power & $y=a^{\star} b^{\wedge} x$ & 37.553 & 1.174 & & 37.514 & 0.566 & Fig. 2 \\
\hline & $\begin{array}{l}\text { moss layer biomass standard } \\
\text { deviation (all points) }\end{array}$ & Modified Power & $y=a^{\star} b^{\wedge} x$ & 42.969 & 1.213 & & 101.661 & 0.354 & Fig. 3 \\
\hline & $\begin{array}{l}\text { moss layer biomass standard } \\
\text { deviation (St. Petersburg excluded) }\end{array}$ & Modified Power & $y=a^{\star} b^{\wedge} x$ & 25.186 & 1.299 & & 31.248 & 0.856 & Fig. 3 \\
\hline & moss layer biomass (all points) & Modified Power & $y=a^{\star} b^{\wedge} x$ & 146.599 & 1.149 & & 191.310 & 0.370 & Fig. 3 \\
\hline & $\begin{array}{l}\text { moss layer biomass (St. Petersburg } \\
\text { excluded) }\end{array}$ & Modified Power & $y=a^{\star} b^{\wedge} x$ & 108.916 & 1.195 & & 98.190 & 0.704 & Fig. 3 \\
\hline
\end{tabular}


biomass depends heavily on local habitat factors. This is also suggested by the finding of a correlation between herb layer biomass and the degree of base saturation in the eluvial horizon (VE), with the
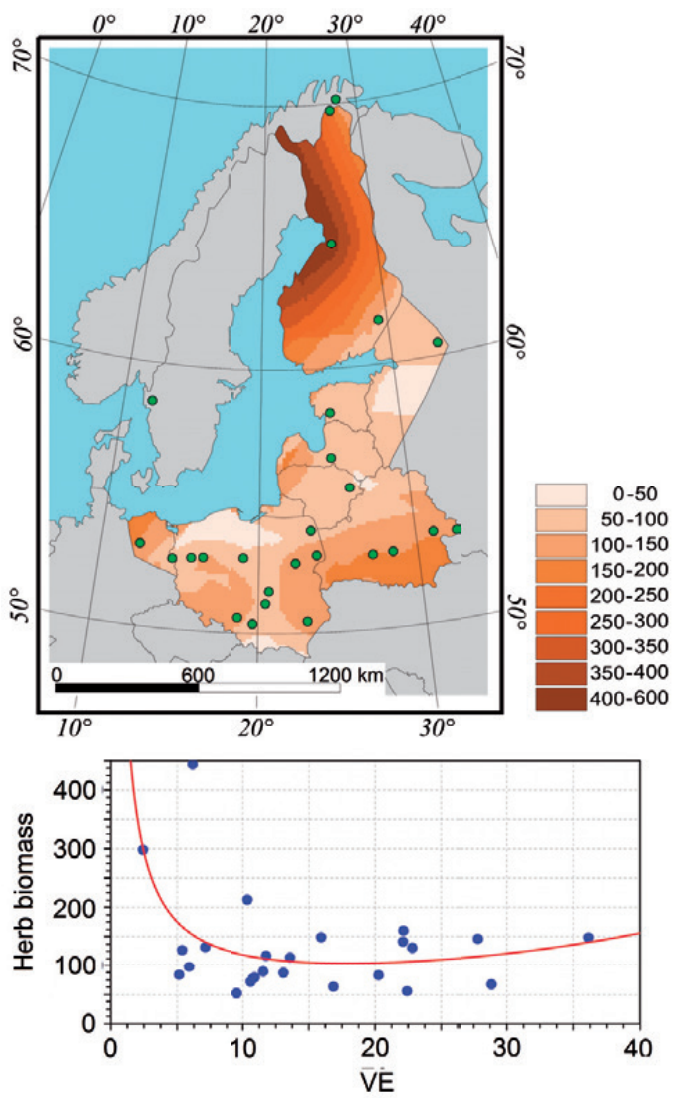

highest biomass figures usually co-occurring with low saturation parameters, and biomass being almost stable (in the range from 50 to $150 \mathrm{~g} / \mathrm{m}^{2}$ ) when VE is higher than 10 (Fig. 2; Tab. 2).
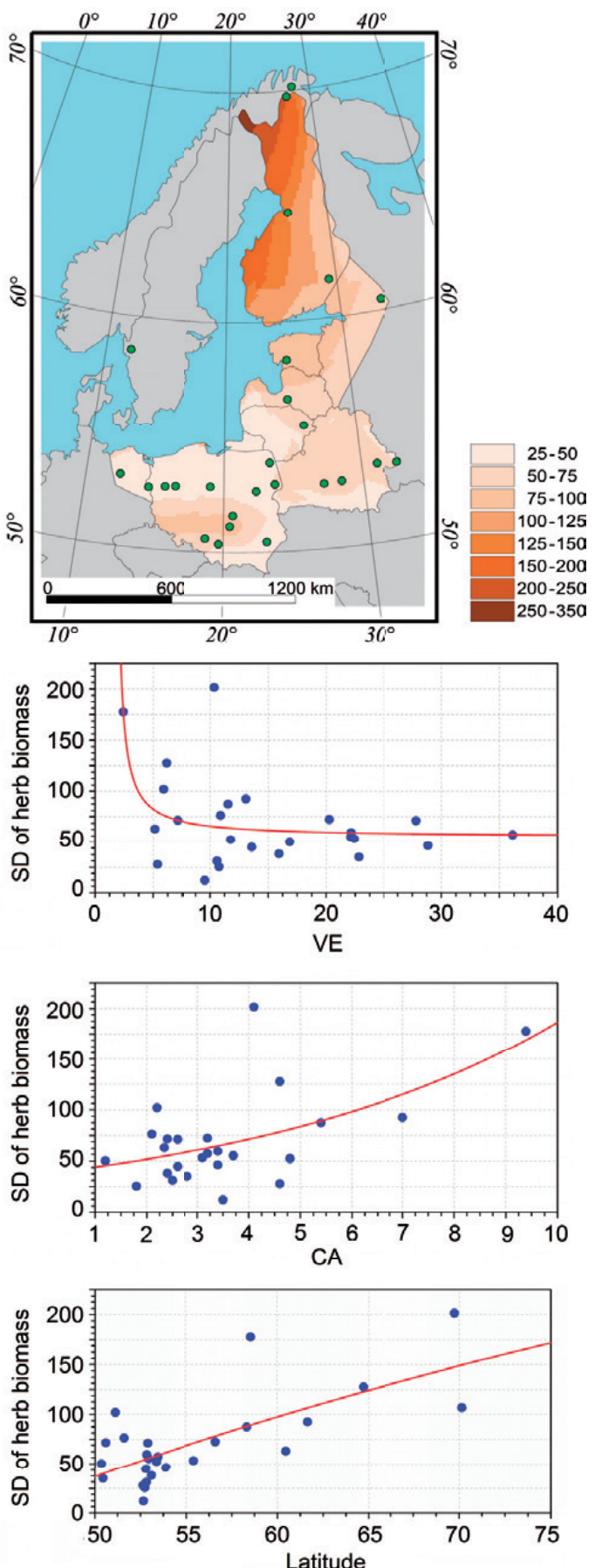

Figure 2. Spatial differentiation of mean herb layer biomass (left) and herb layer biomass standard deviation (right) and their correlations with selected characteristics of the study sites. 
The non-uniformity of biomass distribution in the study sites (represented by its standard deviation) was lowest $(<30)$ at numerous sites in Poland, and highest $(>90)$ at the sites in Scandinavia. Interestingly, besides a statistically significant positive correlation between herb layer biomass standard deviation and latitude (best represented using a logarithmic model), there was also a correlation with the soil organic carbon (CA) content (Modified Power Model) and with the degree of base saturation in the eluvial horizon (VE), with the highest biomass standard deviation figures co-occurring with low saturation parameters and high content of organic carbon (Fig. 2; Tab. 2).

\section{Moss layer biomass}

Moss layer biomass was characterised by a relatively high spatial differentiation (Fig. 3), ranging from $<120 \mathrm{~g} / \mathrm{m}^{2}$ (eastern Germany and most Polish sites, except north-eastern Poland) to $>300 \mathrm{~g} / \mathrm{m}^{2}$ (the Lithuanian site and all sites north of it). Consequently, there was a correlation between moss layer biomass and latitude that was best described with a logarithmic model. The moss biomass also increased with increasing organic carbon content (CA) in the topsoil (Fig. 3; Tab. 2).

The degree of non-uniformity of distribution of moss layer biomass in the study sites (represented by its standard deviation) varied very widely, from $<30$ (eastern Germany and eastern Belarus) to $>300$ (the Swedish, Norwegian and Russian sites). Consequently, there was a correlation between the standard deviation of moss layer biomass and latitude that was best described by a logarithmic model. The standard deviation of moss layer biomass also regularly increased with increasing organic carbon content (CA) in the surface layers of the soil and decreased with increasing base saturation in the eluvial horizon (VE). The pattern of change of the standard deviation of moss biomass along the changes of VE is very similar to the pattern presented by the changes of the herb layer biomass standard deviation, namely a very abrupt decrease when VE reaches the value of 10, and then very slow and not significant changes (Fig. 3; Tab. 2). Of note, sites located south of $55^{\circ} \mathrm{N}$ (Germany, Poland and Belarus) exhibited a weak, but statistically significant, correlation between non-uniformity of herb and moss layer biomass distribution, which was not seen at sites further north (Fig. 4).

\section{Hydrolytic acidity}

Hydrolytic acidity in the A horizon (HA) varied from $<3$ to $>40 \mathrm{cmol}^{(+)} \mathrm{kg}^{-1}$, ranging between 6 and 16 at most sites. Analysis of spatial differentiation did not reveal any overall pattern, which clearly indicates that this parameter depends mainly on local habitat factors (Fig. 5).

Somewhat different findings were obtained with regard to the spatial variation of hydrolytic acidity in the eluvial horizon (HE), which ranged from about 2 to more than $30 \mathrm{cmol}(+) \mathrm{kg}^{-1}$, with values below 5 recorded at most Polish and Belarusian sites. The correlation between hydrolytic acidity in the eluvial horizon (HE) and longitude was best described by the Vapour Pressure Model. Interestingly, no significant correlations were revealed between this parameter and other characteristics of the soil and vegetation (Fig. 5; Tab. 2).

\section{Degree of base saturation}

The degree of base saturation in the accumulation horizon (VA) ranged between approx. 3 and approx. $31 \%$, with a belt of the lowest values extending across central Poland and central Belarus. The degree of base saturation in the eluvial horizon (VE) similarly varied from $<3$ to approx. $36 \%$, with sites demonstrating the highest values of this parameter found in north-eastern Poland, Belarus and in Latvia and Lithuania (Fig. 6). Despite a rather conspicuous pattern of spatial differentiation of this parameter, it was not significantly correlated with latitude or longitude.

\section{Soil organic carbon content}

Organic carbon content in the A horizon (CA) ranged from approx. $1 \%$ in southern Poland to $>6 \%$ in southern Finland and $>9 \%$ in Sweden. This pattern of variation resulted in a correlation with latitude, with the highest values noted at sites between $57^{\circ}$ and $67^{\circ} \mathrm{N}$ (Fig. 7), which was best described with the Vapour Pressure Model (Fig. 7; Tab. 2).

\section{Discussion and Conclusions}

A detailed statistical analysis of the results points to the presence of the following correlations: (a) a rise in the number of vascular plant species in the herb layer as one moves from west to east and 

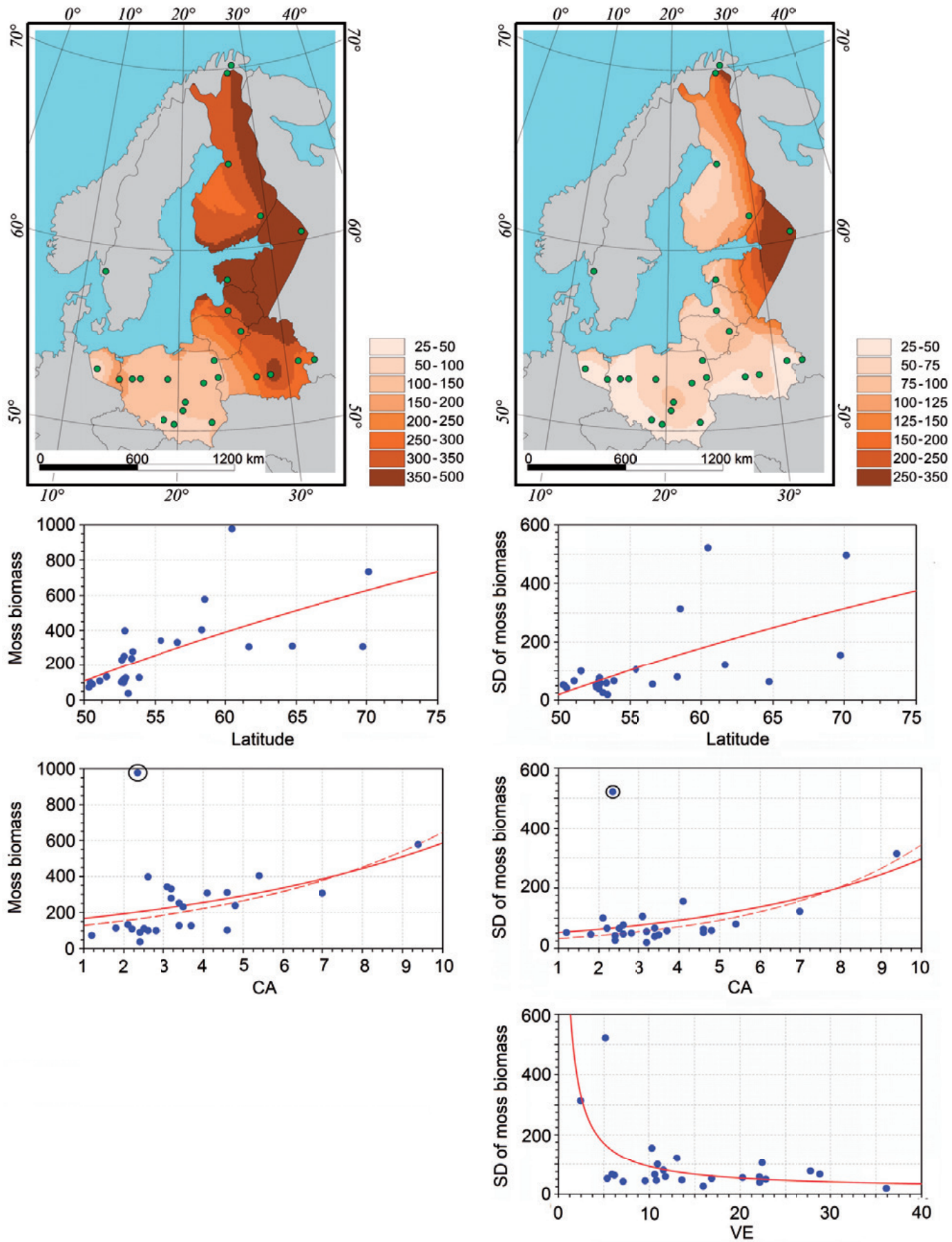

Figure 3. Spatial differentiation of mean moss layer biomass (left) and moss layer biomass standard deviation (right) and their correlations with selected characteristics of the study sites.

from north to south; (b) no significant relationship between geographical location and the biomass of the herb layer, but it is possible to divide the study area into two parts: central Scandinavia, characterized by a high level of biomass, and the rest of the area, characterized by lower herb layer biomass; (c) a south-north increase in the standard deviation of the herb layer biomass (serving also 


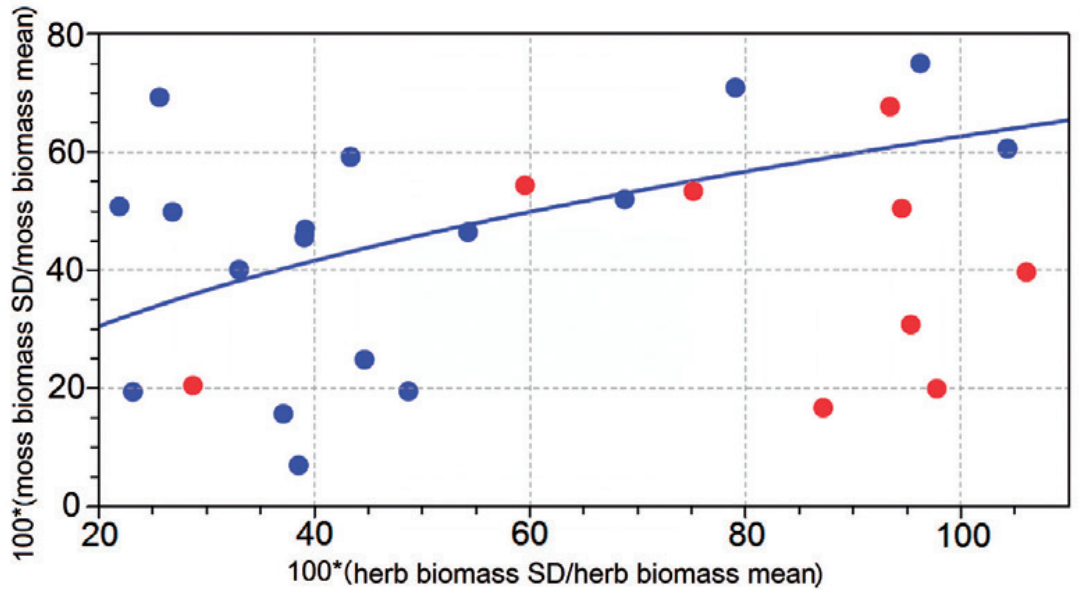

Figure 4. Correlation between variability in herb layer and moss layer biomass in the study sites.

Blue points are sites south of latitude $55^{\circ} \mathrm{N}$, correlation - Power Fit $y=a x^{\wedge} b$; $a=8.0155 ; b=0.4465$; Standard Error 19.1491; Correlation Coefficient 0.4308 . Red points are sites north of $55^{\circ} \mathrm{N}$, no statistically significant correlation.
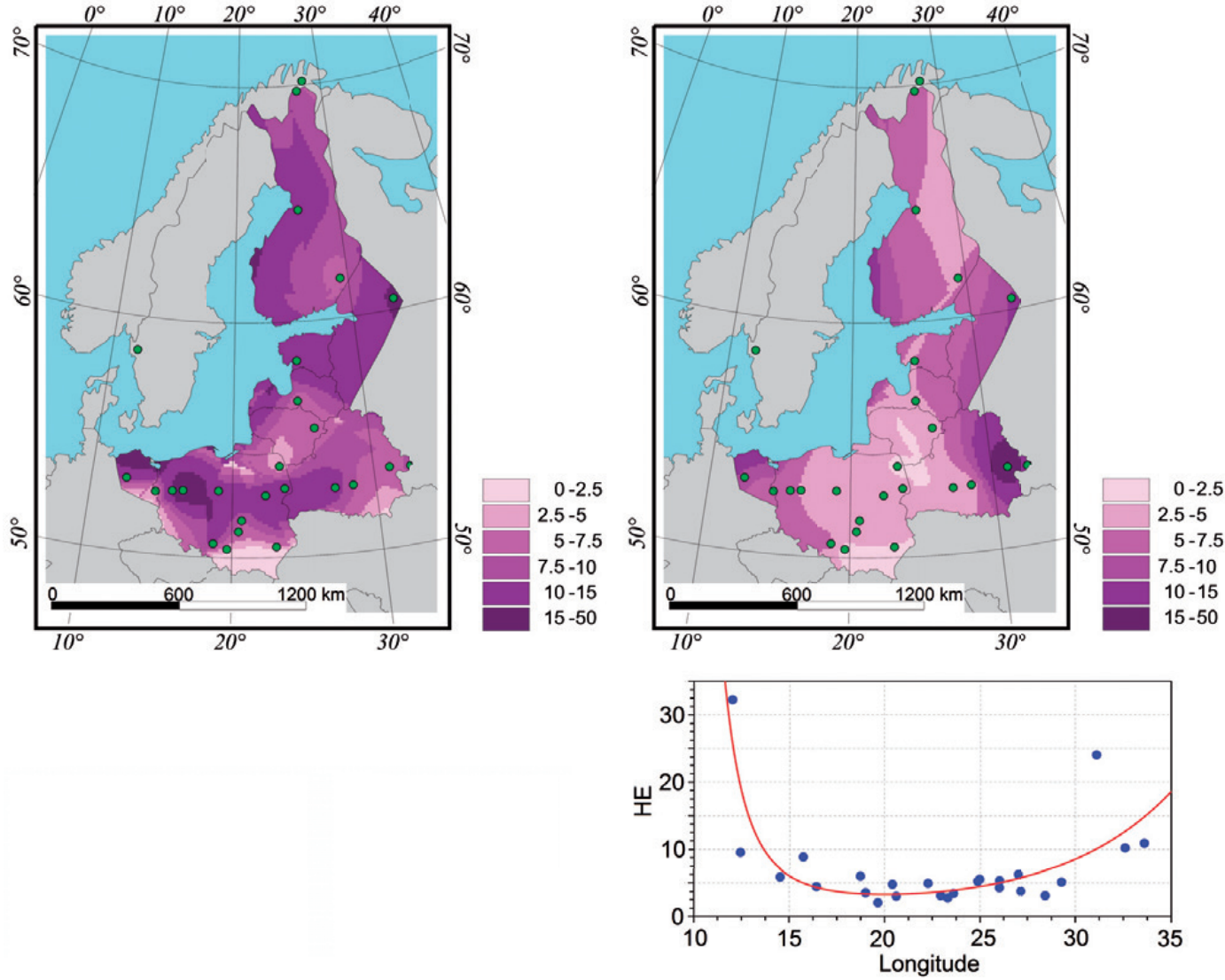

Figure 5. Spatial differentiation of hydrolytic acidity in the accumulation horizon HA (left) and eluvial horizon HE (right) and their correlations with selected characteristics of the study sites. 

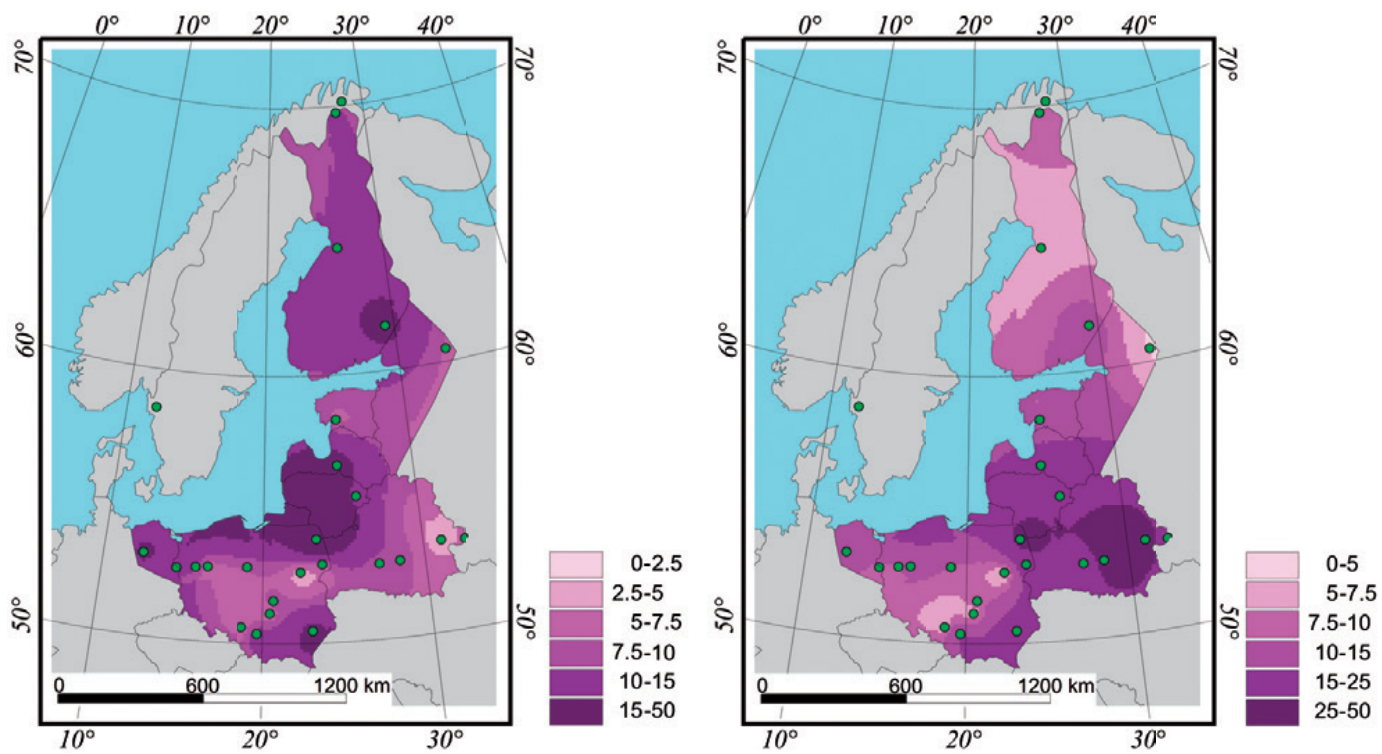

Figure 6. Spatial differentiation of the degree of base saturation in the accumulation horizon VA (left) and eluvial horizon VE (right).

as a measure of spatial heterogeneity of the forest floor in terms of the synusial structure of the community); (d) greater biomass of the bryophyte (moss+lichen) layer in the north than in the south and in the east than in the west; (e) stability of the standard deviation for moss biomass (serving also as a measure of spatial heterogeneity of the forest floor in terms of the synusial structure of the community) at lower latitudes, albeit with a sharp increase north of latitude $55^{\circ} \mathrm{N}$.

The study shows more marked correlations and spatial patterns for soil characteristics of the eluvial horizon (E) compared to the humus horizon (A), particularly with regard to such sorption parameters as the degree of base saturation $(\mathrm{V})$ or hydrolytic acidity $(\mathrm{H})$. It may then be supposed that the eluvial horizon is characterised by greater biochemical stability compared to the humus horizon, which is the site of the fundamental processes of humification and mineralisation of organic matter and a large variety of biochemical processes. The eluvial horizon is poor in nutrients, including organic-iron-aluminum compounds, and its characteristics are therefore more closely linked to geographically varied properties of the lithologic material, associated, among other factors, with the geological history of the region and the duration of exogenous impacts (Degórski 2007).
Generally, it may be stated that:

- The effect of zonal climatic differentiation is mainly seen in north-south variability patterns of such characteristics as herb layer biomass standard deviation, moss layer biomass, moss layer biomass standard deviation, and organic carbon in topsoil, with most of these correlations being non-linear. The age of the soil and time of soil development also play a role here, though these were not clearly shown as statistically significant correlations.

- West-east differentiation was primarily seen with respect to the species richness of the herb layer. Apparently, these findings reflect general biogeographic diversification in Europe. Other correlations observed (such as the spatial differentiation of hydrolytic acidity in the eluvial horizon) may have a more complex nature, reflecting a synergy of the geographical differentiation of the determinants of soil cover development and differences in forest use history.

- In the case of many parameters (such as herb layer biomass, degree of base saturation), differentiation attributable to local habitat conditions is clearly more important than the possible impact of macrogeographic factors. Despite this masking effect of local factors, some general geographic patterns can still be seen, such as an increasing contribution of low 

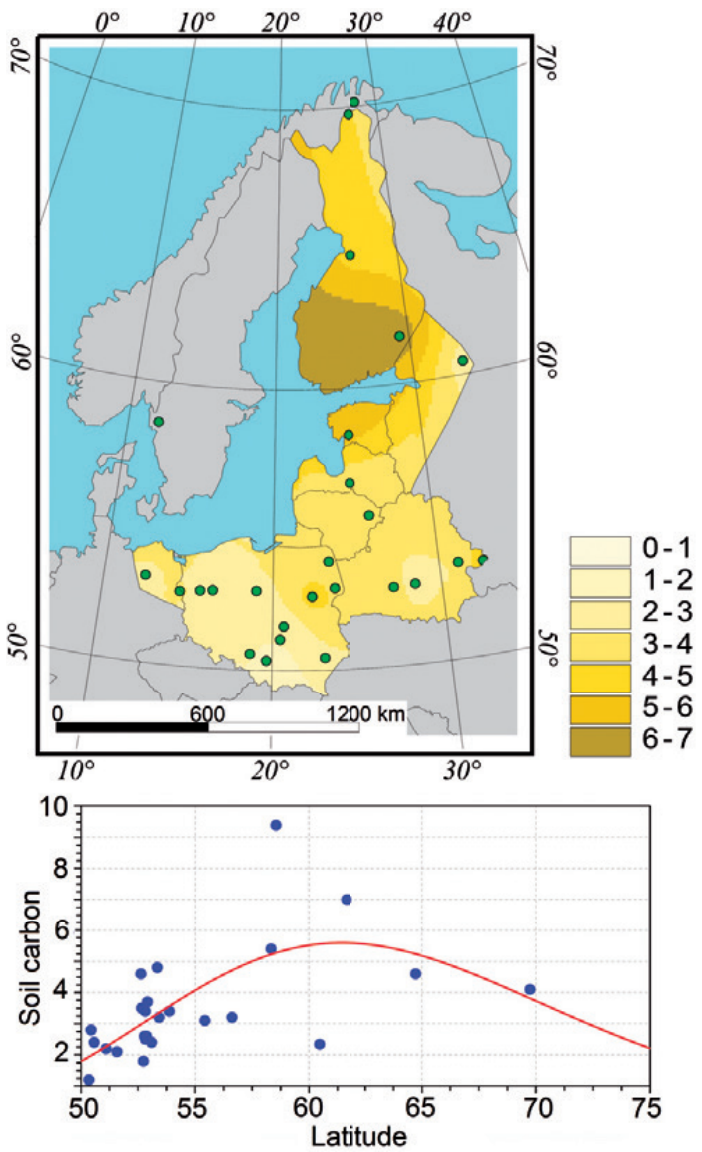

Figure 7. Spatial differentiation of organic carbon content in the accumulation horizon (CA) and a model of variation of this characteristic according to the latitude gradient.

shrubs to total herb layer biomass from south to north (cf. Breymeyer et al. 2006).

These results clearly point to the simultaneous effect of several different mechanisms shaping the structure of soil and the forest floor.

\section{Acknowledgements}

The field results used in this article were obtained within several research programmes:
- "Effects of atmospheric deposition and climate change on forest ecosystems in Eastern Europe and the United States", funded by the USDA Forest Service and the Environmental Protection Agency, USA, in 1993-1998;

- "Biodiversity and matter circulation in forest ecosystems situated on the gradient of air pollution in Poland", research project no. GEF 1/93, funded by the Environmental Protection Agency, USA, in 1994-1997;

- "Patterns of coarse woody debris accumulation and decay on the forest floor of old growth in Białowieża Forest (Eastern Poland) and Hiawatha National Forest (Northern Michigan) - comparative study of protected and managed stands", by II Fundusz im. Marii Skłodowskiej-Curie (Marie Curie Fund 2), funded in 1998-2001;

- "Ecosystems response to climate on a temperate to boreal forest transect", funded by the Environmental Protection Agency, USA, in 1998-2002;

- "Simulating land-use processes - an interactive e-tool for SIA (e-LUP)", funded under the Specific Targeted Project 6 of the EC Framework Programme, Contract No. 018519, in 2005-2009. The following organizations also provided their kind support for these projects: US Environmental Protection Agency; USDA Forest Service; USDA Foreign Agriculture Service (ICD); Bowling Green State University, Bowling Green, Ohio, USA; Michigan Technological University, Houghton, Michigan, USA; Finnish Forest Research Institute; University of Oulu, Finland; Estonian Academy of Science, International Centre for Environmental Biology, Tallinn, Estonia; Latvian Forestry Research Institute; Vytautas Magnus University, Kaunas, Lithuania; Polish Academy of Sciences, Institute of Geography and Spatial Organization, Warsaw, Poland; Polish Bureau of GEF; Forest Research Institute, Sękocin, Poland.

\section{Editors' note:}

Unless otherwise stated, the sources of tables and figures are the author(s), on the basis of their own research. 


\section{References}

Allen A.P., Gillooly J.F., Savage V.M., Brown J.H., 2006. Kinetic effects of temperature on rates of genetic divergence and speciation. Proceedings of the National Academy of Sciences of the United States of America, PNAS, vol. 103, no. 24, pp. 9130-9135.

Breymeyer A., Degórski M., Roo-Zielińska E., Solon J., 2006. Warming, continentality and pollution: large scale forces driving pine ecosystems. Papers on Global Change IGBP, vol. 13, pp. 79-114.

Breymeyer A., Degórski M., Roo-Zielińska E., Solon J., ŚMIAŁKOWSKI J., 1995. Biodiversity and matter cycling in forest ecosystems in the gradient of air pollution in Poland: results of introductory research [in:] P. Paschalis, K. Rykowski, S. Zajączkowski (eds.), Protection of forest ecosystems biodiversity. Warszawa: Fundacja "Rozwój SGGW", pp. 175-191.

Brown J.H., Lomolino M.V., 1998. Biogeography. Sunderland: Sinauer Associates, 691 pp.

Cardillo M., Orme C.D.L., Owens I.P.F., 2005. Testing for latitudinal bias in diversification rates: An example using New World birds. Ecology, vol. 86, iss. 9, pp. 2278-2287.

Clarke A., Crame J.A., 2003. The importance of historical processes in global patterns of diversity [in:] T.M. Blackburn, K.J. Gaston (eds.), Macroecology. Concepts and Consequences, Oxford: Blackwell Scientific, pp. 130-151.

Currie D.J., Mittelbach G.G., Cornell H.V., Field R., Guégan J.F., Hawkins B.A., Kaufman D.M., Kerr J.T., Oberdorff T., O’Brien E., Turner J.R.G., 2004. Predictions and tests of climate-based hypotheses of broad-scale variation in taxonomic richness. Ecology Letters, vol. 7, pp. 1121-1134.

DEGÓRSKI M., 1998a. Charakterystyka morfolitologiczna siedlisk borów i borów mieszanych na transektach badawczych: klimatycznym (wzdłuz $52^{\circ} \mathrm{N}$, od $12^{\circ}$ do $32^{\circ} \mathrm{E}$ ) i "śląskim” [in:] A. Breymeyer, E. Roo-Zielińska (eds.), Bory sosnowe w gradiencie kontynentalizmu i zanieczyszczeń w Europie Środkowej - badania geoekologiczne, Dokumentacja Geograficzna, no. 13, Warszawa: Instytut Geografii i Przestrzennego Zagospodarowania PAN, pp. 31-40.

DEGÓRSKI M., 1998b. Zróżnicowanie fizykochemicznych właściwości gleb siedlisk borów i borów mieszanych na transektach badawczych: klimatycznym (wzdłuz $52^{\circ} \mathrm{N}$, od $12^{\circ} \mathrm{do} 32^{\circ} \mathrm{E}$ ) i "ślqskim" [in:] A. Breymeyer, E. Roo-Zielińska (eds.), Bory sosnowe w gradiencie kontynentalizmu i zanieczyszczeń w Europie Środkowej - badania geoekologiczne, Dokumentacja Geograficzna, no. 13, Warszawa: Instytut Geografii i Przestrzennego Zagospodarowania PAN, pp. 41-54.
DeGÓRSKI M., 1998c. Sezonowa dynamika wybranych gleb siedlisk borów i borów mieszanych na transektach badawczych: klimatycznym (wzdłuz $52^{\circ} \mathrm{N}$, od $12^{\circ}$ do $32^{\circ} \mathrm{E}$ ) i "ślqskim" [in:] A. Breymeyer, E. Roo-Zielińska (eds.), Bory sosnowe w gradiencie kontynentalizmu i zanieczyszczeń w Europie Środkowej - badania geoekologiczne, Dokumentacja Geograficzna, no. 13, Warszawa: Instytut Geografii i Przestrzennego Zagospodarowania PAN, pp. 55-62.

Degórski M., 2002. Przestrzenna zmienność właściwości gleb bielicoziemnych środkowej i północnej Europy a geograficzne zróżnicowanie czynników pedogenicznych. Prace Geograficzne, no. 182, Warszawa: Instytut Geografii i Przestrzennego Zagospodarowania PAN, 189 pp.

DEGÓRSKI M., 2007. Spatial variability in podzolic soils of Central and Northern Europe. Washington: U.S. Environmental Protection Agency, 175 pp.

DobrZAŃSKI B., UzIAK S., 1972. Rozpoznawanie i analiza gleb. Warszawa: Państwowe Wydawnictwo Naukowe, $262 \mathrm{pp}$.

Fischer M.M., Getis A. (eds.), 2010. Handbook of applied spatial analysis. Software tools, methods and applications. Berlin-Heidelberg: Springer-Verlag, $811 \mathrm{pp}$.

Gaston K.J., BlackBurn T.M., 2000. Pattern and processes in macroecology. Oxford: Blackwell Science, $377 \mathrm{pp}$.

Hijmans R.J., Cameron S.E., Parra J.L., Jones P.G., JARVIS A., 2005. Very high resolution interpolated climate surfaces for global land areas. International Journal of Climatology, vol. 25, iss. 15, pp. 1965-1978.

Jefremow A., Degórski M., 1998. Właściwości humusu, biomasa mikroorganizmów i zawartość kwasów nukleinowych w glebach siedlisk borów i borów mieszanych na transekcie klimatycznym [in:] A. Breymeyer, E. Roo-Zielińska (eds.), Bory sosnowe w gradiencie kontynentalizmu i zanieczyszczeń w Europie Środkowej - badania geoekologiczne, Dokumentacja Geograficzna, no. 13, Warszawa: Instytut Geografii i Przestrzennego Zagospodarowania PAN, pp. 63-78.

Kalmar A., Currie D.J., 2006. A global model of island biogeography. Global Ecology and Biogeography, vol. 15 , iss. 1, pp. 72-81.

LOREAU M., 2000. Biodiversity and ecosystem functioning: recent theoretical advances. Oikos, vol. 91, no. 1, pp. 3-17.

Mouillot D., Mouquet N., 2006. Species richness peaks for intermediate levels of biomass in a fractal succession with quasi-neutral interactions. Oikos, vol. 115 , iss. 2, pp. 349-357. 
Roo-ZielińsKa E., SOLOn J., 1997. Effect of geographical location on species composition, vegetation structure, diversity and phytoindicative characteristics in pine forests. Environmental Pollution, vol. 98, iss. 3, pp. 347-360.

Roo-Zielińska E., Solon J., 1998a. Charakterystyka geobotaniczna i analiza zasięgów borów i borów mieszanych na transektach badawczych: klimatycznym (wzdłuz $52^{\circ} \mathrm{N}$, od $12^{\circ}$ do $32^{\circ} \mathrm{E}$ ) i "ślq skim” [in:] A. Breymeyer, E. Roo-Zielińska (eds.), Bory sosnowe w gradiencie kontynentalizmu i zanieczyszczeń w Europie Środkowej - badania geoekologiczne, Dokumentacja Geograficzna, no. 13, Warszawa: Instytut Geografii i Przestrzennego Zagospodarowania PAN, pp. 79-98.

Roo-ZielińSKA E., SOLON J., 1998b. Geographical differentiation of the floristic composition and structure of the herb layer of forest permanent plots in East Germany, Poland and Belarus [in:] A. Bytnerowicz, M.J. Arbaugh, S.L. Schilling (eds.), Proceedings of the International Symposium on Air Pollution and Climate Change Effects on Forest Ecosystems, February 5-9, 1996, Riverside, California, Gen. Tech. Rep. PSW-GTR-166, Albany: USDA Forest Service, Pacific Southwest Research Station, pp. 151-160.

Roo-ZielińsKa E., Solon J., 1998c. Herb layer diversity and phytoindicative evaluation of habitat conditions of forest permanent plots in Poland [in:] A. Bytnerowicz, M.J. Arbaugh, S.L. Schilling (eds.), Proceedings of the International Symposium on Air Pollution and Climate Change Effects on Forest Ecosystems, February 5-9, 1996, Riverside, California, Gen. Tech. Rep. PSW-GTR-166, Albany: USDA Forest Service, Pacific Southwest Research Station, pp. 161-168.

Roo-Zielińska E., Solon J., Degórski M., 2009. Zróżnicowanie borów sosnowych jako efekt uwarunkowań geograficznych i siedliskowych od Holandii do Irkuc-

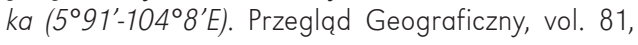
no. 1 , pp. $5-46$.
Solon J., 1998. Różnorodność gatunkowa borów i borów mieszanych na transektach badawczych: klimatycznym (wzdłuz $52^{\circ} \mathrm{N}$, od $12^{\circ}$ do $32^{\circ} \mathrm{E}$ ) i "ślqskim" [in:] A. Breymeyer, E. Roo-Zielińska (eds.), Bory sosnowe $w$ gradiencie kontynentalizmu i zanieczyszczeń w Europie Środkowej - badania geoekologiczne, Dokumentacja Geograficzna, no. 13, Warszawa: Instytut Geografii i Przestrzennego Zagospodarowania PAN, pp. 113-130.

SolON J., 2003a. Scots pine forests of the Vaccinio-Piceetea class in Europe: forest site studied. Polish Journal of Ecology, vol. 51, no. 4, pp. 421-439.

Solon J., 2003b. Changes in herb layer heterogeneity of Scots pine forests along the North-South transect. Polish Journal of Ecology, vol. 51, no. 4, pp. 481-492.

Solon J., Roo-ZIELIŃSKA E., 1998. Zróżnicowanie struktury runa borów i borów mieszanych na transektach badawczych: klimatycznym (wzdłuz $52^{\circ} \mathrm{N}$, od $12^{\circ}$ do $32^{\circ}$ E) i "ślqaskim" [in:] A. Breymeyer, E. Roo-Zielińska (eds.), Bory sosnowe w gradiencie kontynentalizmu i zanieczyszczeń w Europie Środkowej - badania geoekologiczne, Dokumentacja Geograficzna, no. 13, Warszawa: Instytut Geografii i Przestrzennego Zagospodarowania PAN, pp. 99-112.

Solon J., Roo-ZielińsKa E., 2003. Ground vegetation carbon and its relation to climate and species richness. Polish Journal of Ecology, vol. 51, no. 4, pp. 513-527.

Vucetich J.A., Reed D.D., Breymeyer A., Degórski M., Mroz G.D., Solon J., Roo-Zielinska E., Noble R., 2000. Carbon pools and ecosystem properties along a latitudinal gradient in northern Scots pine (Pinus sylvestris) forests. Forest Ecology and Management, vol. 136, iss. 1-3, pp. 135-145.

WRIGHT D.H., 1983. Species-energy theory: an extension of species-area theory. Oikos, vol. 41, no. 3, pp. 496-506. 
http://rcin.org.pl 